\title{
A COMMUNICATIVE APPROACH TO THE TEACHING OF LATIN
}

M. Hermans, B. October and B. van Zyl Smit, in association with J. Boughey, University of Western Cape

\section{INTRODUCTION}

At the University of the Western Cape (UWC) there is a large number of students (about 300) who enrol for the introductory Latin course. Most of these students hope to become lawyers. It is with this in mind that one of the major aims of the UWC Latin course is to enable students to read with comprehension simple Latin texts e.g. The Institutes of Gaius, (cf. Kriel 1982). The prescribed handbook is Legal Latin - A Basic Course by Scholtemeijer and Hasse. There are, however, formidable obstacles in the way of enabling students to achieve the aim of reading Latin with confidence. Some of these are constraints faced by most universities, such as not more than 26 weeks of actual teaching time per year, large groups (80-120 students per group), some apathy because Latin is seen as a compulsory requirement, and often a very genuine fear of Latin as a very difficult subject to pass. At UWC yet another factor has become increasingly important over the past few years. A growing percentage of students are studying Latin through the medium of English while English is not their first language. (At the moment we have one Afrikaans medium group, who are not similarly handicapped).

This paper describes how we attempted during 1992 to make learning Latin a meaningful experience for our students; it also draws some conclusions based on the performance of the students and on feedback obtained from them by means of questionnaires about the course.

The first section deals with problems generally experienced by students, the second with the methodology adopted to deal with these problems and finally there is an evaluation of the procedure and an indication of the road ahead.

Contact time comprised two eighty minute lectures per week dealing with grammar and related experiences, and a weekly tutorial of 40 minutes for which students were divided into groups of approximately 20 . There were approximately 15 tutorial groups, and each group maintained their tutor throughout the year. Students were required to write a weekly practical test for which they had to study the grammar and vocabulary introduced during the previous week. They could also practise their vocabulary and paradigms, and later in the year their setwork comprehension, on the CONSENSUS computer programme.

\section{PROBLEMS}

Many of the problems which manifested themselves in the course of the year will be familiar to teachers of Latin. The following is a brief outline:

Students are inclined to approach Latin at both sentence and text level on a word-for-word basis in sequential order. They tend to write the meaning of each of these words above it and then attempt to make sense of the English words. This form of translation is hampered by a disregard of the principles of inflection and case usage, for example all nouns are put down as nominatives and all verbs as infinitives. An added problem is caused here by the failure to take the context into account in cases where Latin words have more than one 
meaning. A further weakness, which is allied to what may be termed the "learned helplessness" (Winograd \& Niquette, 1988), of the word-for-word approach is the inability to see the Latin text as a connected piece of prose which conveys meaning. This results in students often not being able to see the wood for the trees. Our observation was that this approach often springs from lack of confidence and bewilderment. Very often students, upon being presented with a Latin text, in spite of its containing no words they have not learnt, would immediately start looking up meanings. It often transpired that they actually knew the meaning of the word they were looking up, but were just "making sure". In other words they somehow found some security in establishing the meaning of individual words but were hesitant to try looking at phrases or short sentences as units. A persistent problem is of course that students do not learn the prescribed vocabulary and morphology thoroughly (cf. Smuts 1985) and thus lack the essential tools which they seek to apply.

Further inhibiting factors which had to be addressed were the inadequate command of English of some of the students and the minimal knowledge they generally have about the ancient Romans, their customs and achievements.

Although the educational principles described in this paper informed our course as a whole, these were concentrated in the tutorials. Discussion below will elucidate the methodology we adopted by means of examples.

\section{METHODOLOGY}

In second and foreign language teaching, reading was traditionally regarded as a passive language skill, (along with listening), while speaking and writing were classified as active skills. However, since the 1980 's, reading has been viewed as a process of creating meaning through interaction between reader and text (Silberstein 1987). This interactive process is simultaneously "top-down", utilising the reader's world knowledge and prior knowledge of the content, and "bottom-up", calling on the reader's knowledge of grammar and vocabulary. In our course we have tried to facilitate both aspects of the process. Thus, from a "top-down" perspective we have encouraged students to activate their prior knowledge, build up a framework or context and set up predictions or hypotheses about text content; from a "bottom-up" perspective we have made texts "user-friendly" by making sure that they are within syntactic and lexical reach of the students. (This has been achieved variously through re-writing, editing of extant material and use of supplementary visual material or glossaries of new words). A major aim has been to persuade students that they have sufficient background knowledge and knowledge of the language to approach confidently a Latin text holistically as a piece of discourse, rather than in trepidation or resentment as an atomistic exercise in translation. We have also tried to reduce anxiety by encouraging students to work on texts in pairs or in small groups.

Over the year we have used a selection of texts, including songs, poems, stories, texts on the Roman way of life and simplified legal texts. We, as the Latin lecturers, collected several texts and in collaboration with one another we decided which texts were suitable and in which way they would be presented to the students. We would now like to illustrate our methodology using three of these texts. Each text is accompanied by suggestions for classroom procedure. 


\section{EXAMPLE A DE MILITE ROMANO 1}

miles romanus, quem hic videmus, non togam habet, sed loricam. sub lorica miles quoque tunicam gerit. galea caput tegit. bracchio sinistro miles scutum gerit. dum pugnat, scuto corpus tegit. dextra manu miles pilum tenet. pilum longum est; saepe miles duo pila habet.

praeterea miles gladium habet. gladius nunc in vagina est, sed cum pugnat, miles gladium e vagina educit et hostem gladio necare temptat. galea et lorica et scutum sunt arma; gladius et pilum sunt tela. vincere militem romanum res difficilis erat, nam semper fortis erat nec umquam eum hostis terrebat.

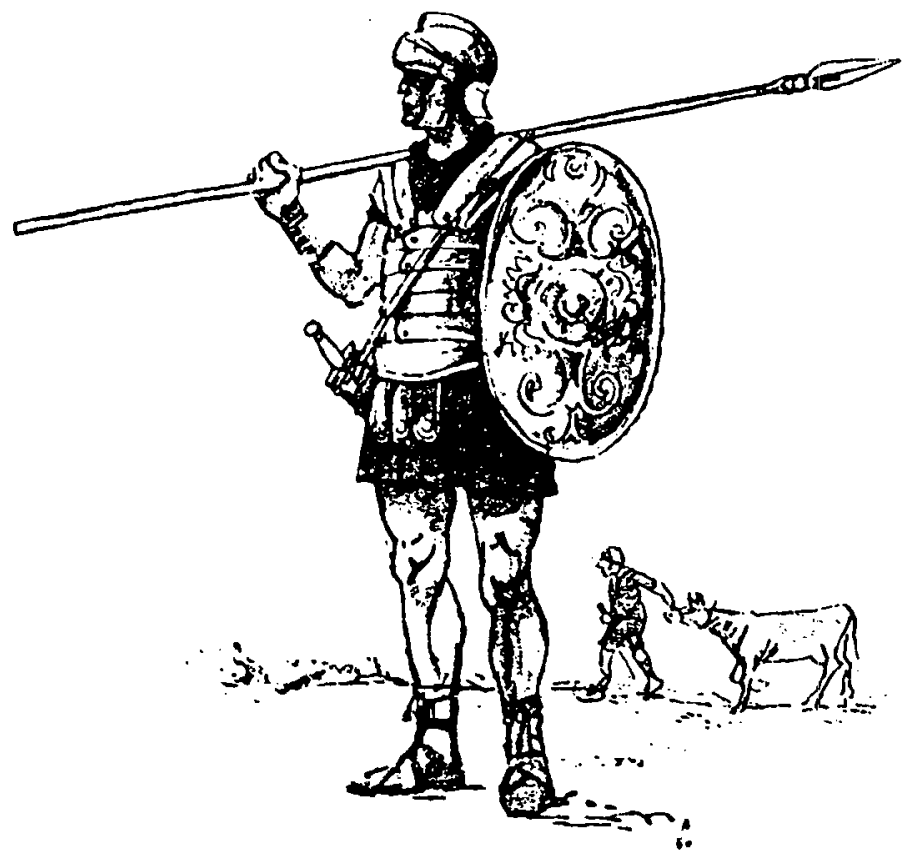

This passage is taken from De Man and Te Riele, 1973. 


\section{METHOD OF TEACHING}

1. Before giving out the text, orient students by asking them how the Romans occupied and then maintained control over territories. Lead up to a focus on the Roman legionary.

2. If an overhead projector is available, display a slide of the picture above. (If not, distribute the text with the picture). Ask students if they can label it in their own language.

3. Students read the text and label the diagram in Latin, writing on the diagonal lines provided. To discourage guessing, not all of the labels are included in the text, (for example the sandals and the belt).

4. Building outwards from these single words, one can then look at the phrases or word clusters in which they appear. There are certain constraints on what a soldier can do with arms and armour, (i.e. have, wear, carry, hold, etc.), and their location, (in the left/right hand, on the head, under the tunic, etc.)

\section{EXAMPLE B THE TEACHER OF FALERII}

The teacher in an Etruscan city, Falerii, decides to hand over his pupils to the Romans. The Romans are the enemies of the people of Falerii.

Obsidebann olim Romani Falerios, urbem Etruscorum, nec expugnare poterant. Sed erat magister, cui principes urbis liberos suos mandaverant. Pueros in castra Romana ad Camillum, qui tum fuit imperator Romanorum, duxit. "Ego", inquit, "ad te liberos duxi, quorum patres sunt primi Faliscorum cives eosque tibi tradere volo. Sic urbem Falerios in potestate tua habebis". Camillus, "Sceleste" inquit "arma ferimus non contra liberos, qui se defendere non possunt, sed contra viros".

Inde liberis magistrum tradidit; qui virum scelestum virgis in urbem egerunt. Falisci fidem Romanam laudaverunt. Petiverunt pacem. Nuntii ad Camillum missi sunt: urbs Falerii omnium civium consilio Romanis tradita est.

\section{METHOD OF TEACHING}

1. Students read the introduction in their own language. Having "set the scene", the teacher then encourages students to set up hypotheses and predict how the text will unfold by asking a series of questions. (This is contrary to the normal practice of asking comprehension questions after the text). For example: In what circumstances might such an act be necessary? Why would a teacher want to hand over his pupils to the enemy? (To save the children? To save his own skin? To betray the city?) What will be the reaction of the enemy? (Gratitude? Indifference? Contempt?)

Words which are italicized in the text are explained in the glossary which is omitted here. 
2. Students are directed to the glossary of new words underneath the text, and are assured that they have encountered all the other words in the text before. They are asked not to consult their dictionaries but rather to discuss the text with their classmates and, if necessary, with their teacher or tutor. They then read the text either to confirm or reject their hypotheses. The important thing is not that their predictions should necessarily be accurate but that they should have established a purpose for reading the text.

3. Students and teacher then compare their interpretations of the text, dealing with the grammatical and lexical items which have proved problematic.

\section{EXAMPLE C DE LEX AQUILIA / CONCERNING THE LEX AQUILIA}

This law provided remedies against loss wrongfully caused to property. It remains of interest today because it addresses the notion of culpability in delictual actions.

Lex Aquilia plebiscitum est. Plebiscitum est quod plebs iubet atque constituit. Eam Aquilius tribunus plebis a plebe rogavit. Ea lex omnibus legibus derogavit.

Si servus ancillave iniuria occissus est, lex Aquilia locum habet. Non sufficit eum occissum esse, sed oportet iniuria id esse factum.

Itaque si magister in disciplina servum vulneravit occideritve, ex lege Aquilia tenebitur. Species talis proponitur apud Iulianum: magister puerum virga percussit, et oculum puero percussit. Dicit igitur lulianus, "Iniuriarum quidem actione non oportet magistrum teneri, quia non faciendae iniuriae causa percussit sed monendi et docendi causa".

\section{METHOD OF TEACHING}

1. Students read the introduction. The tutor initiates a discussion about the different types of "laws" which existed in ancient Rome, eg. senatusconsulta, edicta, constitutiones, leges, plebiscita, etc. The struggle between the plebs and the patricians will probably also be raised.

2. The tutor asks the students whether they have come across Aquilian actions in their law subjects. (This provoked a marked response, and one student summarised the topicality by saying that this action was applicable in every case arising out of an action involving motor vehicles!)

3. Now the students could be asked to read the second paragraph and to formulate clearly what important qualification there was for the application of the Aquilian law.

4. The last paragraph may be approached by first asking the students to describe the example Julianus cites where the lex Aquilia is not applicable. They could be asked who supports the interpretation of Julianus and who disagrees with it. (This again produced a lively exchange of opinions). 
5. Finally, the tutor ensures that students understand the grammar, especially such constructions as the gerund and the gerundive.

\section{EVALUATION OF THE METHOD}

During the course of the year we handed out two questionnaires to our students to assess their attitudes towards tutorials, how regularly they attended, how beneficial the tutorials were, and what comments they had for improving the tutorials and the course. It is from these questionnaires, in particular the second one, that we can determine the students' response to the communicative approach to teaching Latin. From the responses of the tutors themselves, based upon their own observations, we have tried to assess how successful the methods were which we used in the presentation on continuous Latin prose in tutorials.

In the first semester we read only one short piece of continuous prose (a simplified extract from Gaius, entitled de interdictis). Nevertheless, when asked what they liked best about the tutorials during the first semester, $20 \%$ of the students mentioned this passage. In the second semester, where many more passages were read, this trend continued. Students responded that they enjoyed the novel approach to the presentation of continuous Latin prose, and specifically asked for more tutorials of such a nature. They also responded that the tutorials were not only enjoyable, but that such an approach helped them to analyse sentences and improved their ability to translate sentences.

The tutors observed that the confidence of some students increased with the introduction of continuous Latin prose. Unlike the case with single, "random" sentences, students could now also use the context to help them understand what any particular sentence meant. Despite this, there was still the tendency to refer to the vocabulary list. This was discouraged, and with a little prompting students realised that they could deduce what a word meant from the context. In this way the self-confidence of the students increased, and the cycle was complete. With more self-confidence, students were less daunted by Latin texts, which, in turn, increased their confidence even further.

Tutors also noticed that the texts which the students found easier to work with, were the ones in which there were short sentences, the vocabulary was familiar, and where the topics caught their attention. We kept these things in mind when we selected and adapted the passages. The first few passages which we gave to the students therefore contained simple constructions, known vocabulary and relatively short sentences. As the confidence and the ability of the students increased, so too did the length of the sentences and the difficulty of constructions. We also used supporting diagrams in the first few passages, lest the students became daunted at being confronted by a Latin text only.

Another factor which increased confidence was the fact that students worked in groups. $3 \mathrm{~A}$ group seldom consisted of more than three or four students. Some of the advantages of group work were that students could ask one another questions about grammatical constructions and vocabulary. Some students felt that fellow students could help them solve their problems in a way that they could understand.

3 A small percentage of students were not so keen on the prospect of working in groups. Among the reasons that they supplied for this were that the work did not get done, fellow students could not explain how they had arrived at a particular answer, and that students in the same group were at different levels of understanding. 
Besides the positive comments which the students made about the tutorials, there were also some negative ones. One of these was the time constraint. Students found that 40 minutes were too short a time within which to complete the tutorial exercise. There were students who suggested that there be two tutorial sessions every week. Another suggestion was that the students bring prepared work to the tutorial.

Tutors noticed that there was still the tendency among certain students to analyse sentences word by word and to translate in a linear fashion, irrespective of the case endings. They did this despite the fact that the scene had been set for them and that they knew, more or less, what the context was. This is perhaps a result of the fact that Latin passages were used intensively only from the second semester.

\section{CONCLUSION}

We have described an attempt to instil greater confidence in our students, and have tried to make them more at ease with the Latin language. In spite of this, students' performance in the grammar and unseen sections of the final examination was still not satisfactory. As is so often the case, the marks obtained in the examinations do not reflect the progress that lecturers and students feel they have made during the year. However, there are enough indications to encourage us to continue and develop this process next year. (Watch this space!)

\section{BIBLIOGRAPHY}

De Man, A.G. and Te Riele G.M.J.J. 1973. Lectio Continua. London: John Murray.

Kriel, D. 1982. "Section 1: Aims and Objectives - The Specification of Objectives". Akroterion XXVII, 3\&4, 82-88.

Silberstein, S. 1987. "Let's Take Another Look at Reading: Twenty-five Years of Reading Instruction". English Teaching Forum XXV, 4, 28-35.

Smuts, F. 1985. "Reading a Latin Passage". Akroterion XXX, 3, 73-78.

Winograd, P. and Niquette, M.C. 1983. "Assessing Learned Helplessness in Poor Readers". Topics in Language Disorders 8(3), 38-55. 